\title{
The age of quality innovation
}

Sang M Lee

Correspondence: slee1@unl.edu University of Nebraska-Lincoln, Lincoln, USA

\begin{abstract}
In this inaugural issue of International Journal of Quality Innovation, the Editor-in-Chief reports the evolution of quality management and the need for innovative research for creating new quality values.

Keywords: Evolution of quality concepts; Age of quality innovation; New quality values
\end{abstract}

\section{Evolution of quality management}

Quality management has been with us from the very beginning of human history. In the hunt and gathering economy, humans worked day and night to find enough food, shelter, and clothing to survive. They had very limited choices and often had to do with whatever they could find. Thus, the level of quality management was almost nonexistent. As people began to accumulate knowledge about better ways to secure the food they needed to survive, the agricultural economy was born. Humans began to plant crops and grow livestock for sustainability. Still, the demand exceeded supply for a comfortable living, and quality management was rudimental at best.

With the arrival of the industrial revolution, people began to produce goods in a much more effective way and the luxury of choosing the best good to use became the basic quality management focus among affluent people. In the 19th and 20th centuries, a massive industrialization took place and the information economy gradually became a reality in the later half of the 20th century. Supply began to exceed demand for most goods and producers began to aggressively market their goods to attract customers through advertising and marketing. One of the key strategies for attracting customers for market expansion was quality management, offering customers what they needed and wanted. Today, we live in the innovation and convergence economy. Several mega trends (e.g., globalization, digitization, changing industry mix, changing demographics, commoditization of value chain processes for products and services, the exploding emerging economies, and the deteriorating environment) have helped open the era of innovation and new value-creating opportunities through convergence.

Today, many innovative applications of the Internet (e.g., Internet of Things: IoT, Internet of Everything: IoE), cloud computing, robotics, transportation technologies, big data analytics, social network services, artificial intelligence, and convergenomics [1] are helping organizations and individuals create new value that most people did not even realize they were missing. This means that there are massive new opportunities to develop new products and services that generate both supply and new blue ocean markets [2]. In this new environment, the concept of quality has dramatically

(c) 2015 Lee; licensee Springer. This is an Open Access article distributed under the terms of the Creative Commons Attribution License (http://creativecommons.org/licenses/by/4.0), which permits unrestricted use, distribution, and reproduction in any medium, provided the original work is properly credited. 
changed from the conventional utilitarian focus. This broad-stroke generalization provides a glimpse that the concept of quality is subject to a changing environment and competitive ecosystem.

\section{(1) Early quality concepts and management systems}

Quality management has been a major concern of people throughout history. For example, skilled Egyptian architects, surveyors, stone cutters, and builders used high quality measures to built miraculously large pyramids (e.g., The Great Pyramid of Giza, circa 2,560 BC). During the helm of Emperor Qin Shihuang in China's Qin Dynasty (221-210 BC), expert builders erected the Great Wall and skilled sculptors designed thousands of Terracotta soldiers, all based on precise standards of quality. During the Middle Age in Europe, the system of craftsmanship was established to train skilled workers who produced quality goods and services through the career steps of apprenticeship, journeymen, and masters. Suffice to say, some sort of quality management system existed in almost every country throughout its economic and cultural development.

The late 19th century until World War II could be described as the "producer centric" economy. Taking advantage of the rapidly developing industrial technologies, manufacturers began to mass-produce goods through assembly lines, Frederick Taylor's Scientific Management, human resource management systems, and the like, as all they produced was gobbled up by consumers [3]. However, with the accelerating volume of production, consumers began to have a choice in selecting the goods they wanted. Thus, manufacturers began to use some sort of "product-focused" quality control. The product engineers and process designers began to pay attention to the specifications required for the product; thus the initial quality concept meant to meet the standards and specifications that defined the attributes of the product (e.g., usability, performance, reliability, durability, conformance, serviceability, etc.). Consequently, the initial quality management system dealt with inspection for detecting defects in meeting the specifications. The inspection method used was based on Shewhart's control chart at the Bell Labs and the statistical process control (SPC) was born [4]. Many of the quality gurus (Walter Shewhart, Harold Dodge, Joseph Juran, and W. Edwards Deming, among many others) served in the quality inspection department of Western Electric Company in the 1920s [5].

\section{(2) The middle 20th century}

After World War II, U. S. firms were primarily concerned with producing sufficient amounts of goods to satisfy the increasing consumer demand. Thus, quality management was relegated to the quality control and inspection department. However, most human talents dedicated to the war efforts soon returned to the private sector, and the supply of goods soon met or exceeded demand. Business firms began to recognize quality as a source of competitive advantage. Several important quality management approaches were introduced around this time:

Joseph Juran's Quality Control Handbook (later published as Juran Trilogy, [6]), Armand Feigenbaum's Total Quality Control [7], W. Edwards Deming's integrated concept of quality (later became the 14 Points of Quality Management, [8]), Philip Crosby's Preventive Quality Management [9], among others. Right after World War II, the 
defeated Japan requested the help of the U. S. government in its efforts to rebuild its devastated economy. Drs. Juran and Deming were sent to Japan to help the Union of Japanese Scientists and Engineers (JUSE) as consultants to teach the concepts of quality, statistical process control and total quality control (TQC). Japanese manufacturers pursued these quality principles to develop Kaizen (continuous improvement) and subsequently a system known as company-wide quality control (CWQC).

\section{(3) Total quality management and business excellence models}

In the post war era, American firms became complacent, due to the political and economic leadership of the country. Simultaneously, Japanese firms had the sense of urgency to rebuild its economy through export of manufactured goods. Armed with the knowledge of CWQC, pursuit of excellence, highly motivated and cheap manpower, and the newly opening global market, Japanese firms became formidable competitors. Many western firms visited Japan to benchmark Japanese CWQC, Toyota's just-in-time system (e.g., quality at the source and quick response systems), and bottom-up management systems (e.g., quality circles). Based on this new knowledge, U. S. firms developed the concept of total quality management (TQM) [10]. Many new innovative quality programs have since developed, such as Motorola's Six Sigma, ISO 9000 series, Toyota's Lean Management, and the like [11]. Thus, quality became not simply the concern of the manufacturing process (Little q) but the strategic imperative for the entire organization (Big Q) [5].

With the fall of the Berlin Wall in 1989, globalization became a reality. To compete in the global marketplace, quality is an essential requirement for market success. Japan established the Deming Prize in 1951 to recognize the quality accomplishments of Japanese firms. The U. S. Department of Commerce established the Malcolm Baldrige National Quality Award (MBNQA) in 1987 to promote the principles of TQM in manufacturing/service industries and not-for-profit organizations. The European Foundation for Quality Management (EFQM) launched its own quality award, the European Quality Award (EQA), in 1992. Since then, a number of countries followed suit to establish national quality awards, all based on the general frameworks of Deming Prize, MBNQA, and EQA. Also, similar awards have been established in different industries, such as health care.

\section{(4) Quality innovation}

In the fast evolving global economy and with the increasing manufacturing prowess of emerging economies in the new millennium, there has been a dramatic change in the industry mix in advanced countries. For example, in the U. S. today, manufacturing has less than $13 \%$ of jobs, agriculture about $2 \%$, governments $5 \%$, with the remainder in the service sector, especially in knowledge-intensive industries such as biotech, health care, ICT, logistics, hospitality and tourism, entertainment, education, and the like. Consequently, quality management has gradually developed to include service excellence. Thus, SERVQUAL has become a popular research topic [12]. Even for manufactured goods, product quality alone has become insufficient to attract customers and gain their loyalty. As a matter of fact, the most significant financial return no longer comes from simply selling a product, but from downstream after-sale services such as maintenance, upgrades, warranties, financing and 
the like. Products need to be packaged with service innovation to provide value that can delight customers. iPhone apps, warranty packages for home appliances, the navigation system and SiriusXM Radio package for new automobiles, etc. are good examples. Thus, many firms have developed the product service system (PSS) to offer new customer value through an integrated package of products and services.

Today, the concept of quality has long passed the traditional utilitarian standards and measures. Producing global quality goods and services at reasonable price is simply a market entry requirement. In addition, customers also expect speed in delivery and opportunities for customization. New customer value now includes hedonic qualities such as a sense of safety and security, aesthetics, well-being, engagement, and participation. Furthermore, many customers seek opportunities to experience the process of value creation or co-creation with the producer. Many new ventures are even being created for sharing (Uber, Lyft, Airbnb, Apple's App Store, etc.), co-creation (e.g., user generated content, do-it-yourself (DIY) agricultural tourism, archeological tourism), and the like. Another new customer value is environmental sustainability. Customers are not only interested in, but also active partners with corporations for "being green" (e.g., ISO 14001, ISO 24000).

Today, quality management is no longer concerned with producing and selling "fit to use" goods to the customer. Instead, it is directly tied to the strategic imperative of organizational innovation for world-class performance. Thus, the task of quality management is not only to explore what the customer needs based on the customer centric perspective, but to co-create what the customer will need in the future in collaboration with other stakeholders including suppliers, employees, the general public (crowd sourcing), partner organizations, governments, and even competitors. Quality management now falls under the umbrella of organizational innovation. Innovation can be defined narrowly as scientific breakthroughs, inventions, patents, and new technologies. However, in the realm of management, we should define innovation broadly as " the ongoing process of exploring for new ideas or approaches that can be applied differently than before to create new or greater value" [1,13]. There are different types of innovation such as incremental, disruptive, and radical. Quality innovation can be involved in any of these types, but disruptive and radical innovations will bring quantum changes to the concept of quality.

There are many possibilities for value creation through organizational innovation. The most widely recognized areas are developing new products, services, or ventures; redesigning the value chain architecture for greater efficiency; reinventing the concept of customer value; expanding the customer base; and introducing new business models [1]. Quality innovation can take place in any of these five areas. However, the development of new products/services and creating new customer value should be the primary foci for their obvious impact on performance excellence.

Organizational innovation has evolved over the years from Innovation 1.0 -closed innovation (e.g., Proctor \& Gamble - "Invented here"; NASA - "As only NASA can") to Innovation 2.0 - collaborative innovation (e.g., collaborative value chains with partner organizations), to Innovation 3.0 - open innovation (e.g., searching for any viable source of new ideas, including collective intelligence and crowd sourcing), and now to Innovation 4.0 - co-innovation (e.g., integrating collaborative, open, and co-creating innovations through a unique organizational convergence platform) [13]. We are now in 
the co-innovation age of quality management where organizations are open for collaboration, co-creation, and use of leading-edge technologies for value creation. Today, advanced mobile technologies, wearable devices, IoT, IoE, cloud computing, ubiquitous computing, sensing devices and machine learning based artificial intelligence allow organizations to collect big data and use analytics to extract valuable information. Many social network and mobile ICT firms have accurate information about customers' tastes, behaviors, life styles, latent needs, and even inner feelings. The real key of effective coinnovation for quality management is how to transform such high-order information into accurate and useful business intelligence. The organization should develop a convergence platform with its unique tacit knowledge about core competencies required to satisfy its customers' current and future needs. Such a convergence platform is inimitable - and thus sustainable - to leverage the competitive advantage of the organization. This researcher and colleagues have been exploring the application of "design thinking" principles to co-innovation for quality excellence, "design for quality innovation (D4QI)."

\section{The inaugural issue of International Journal of Quality Innovation}

I am truly honored to launch the International Journal of Quality Innovation as its Editor-in-Chief. This effort has become possible because of the tireless support of Mr. Nicholas Philipson, Editorial Director for Business, Economics and Statistics of Springer Publishers. The journal will be partially supported by the Korean Society of Quality Management under the leadership of President Dr. Wan Sun Shin and the former President, Dr. Hanjoo Yoo. Dr. Jeongil Choi of Soongsil University, Korea will serve as the Associate Editor. The Editorial Board of the journal is composed of renowned experts in the fields of operations, supply chain management, quality management, and innovation throughout the world. Most people hold distinguished university professorships and directorships of research centers at their respective institutions, have served or currently serving as presidents of professional organizations, and/or editors-in-chief of global journals. I am totally confident that this journal will make important contributions to the field and become a success under the guidance of such distinguished professionals.

Received: 11 January 2015 Accepted: 21 February 2015

Published online: 21 May 2015

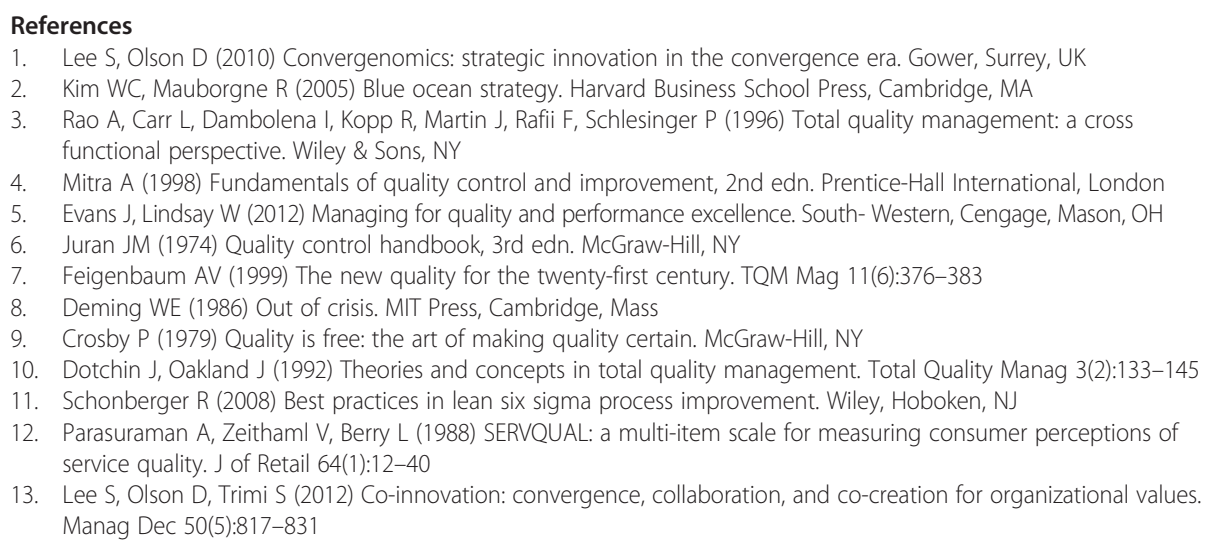

